\title{
Rozwój regionalny Litwy w warunkach integracji gospodarczej
}

Agata Gasińska*

\section{Wstęp}

Gospodarka światowa nieustannie się rozwija. Progres, który bezspornie można dziś obserwować - w większym lub mniejszym stopniu - na świecie, wpływa na to, co będzie za kilkadziesiąt czy kilkaset lat. Rozwój gospodarczy wskazuje pozycję kraju na tle międzynarodowym, jest dynamiczny i odzwierciedla zmiany zachodzące w państwie.

W pracy została podjęta tematyka rozwoju regionalnego Litwy w warunkach integracji gospodarczej, gdyż to właśnie ona ułatwia dynamizowanie procesów rozwojowych. W pracy określono też istotę integracji ekonomicznej. Przeanalizowano rozwój regionalny Litwy w latach 2004-2015, scharakteryzowano regiony Litwy pod względem podziału administracyjnego, a także poruszono kwestię źródeł finansowania rozwoju Litwy. Ostatecznie dokonano analizy rozwoju regionalnego Litwy w warunkach integracji ekonomicznej, uwzględniwszy takie czynniki jak PKB, stopę bezrobocia i zatrudnienia.

Celem artykułu jest przeanalizowanie poszczególnych regionów Litwy, tak aby zaprezentować poziom ich rozwoju oraz wskazać wewnętrzne, regionalne zróżnicowania kraju, a także określić - na podstawie wykorzystania dostępnych środków pomocowych - wpływ Unii Europejskiej na wzrost gospodarczy Litwy. Analizy dotyczą lat 2004-2015.

\footnotetext{
* Agata Gasińska - licencjat z ekonomii, Uniwersytet w Białymstoku, Filia w Wilnie, Koło Naukowe Studentów Ekonomii im. F.A. von Hayeka Wydziału Ekonomiczno-Informatycznego w Wilnie, gasinska.agata@gmail.com.
} 


\section{Istota integracji gospodarczej}

Pojęcie „integracja” istnieje już od kilku stuleci. Według Oxford English Dictionary pierwszy raz pojawiło się w druku w 1620 roku. W języku łacińskim terminu „,integracja” używano w znaczeniu renowacji i odnowienia (Machlup 1986, s. 17). Obecnie funkcjonuje wiele definicji integracji.

Samo słowo pochodzi od łacińskiego integratio, co oznacza scalanie, zespalanie, łączenie. Dotyczy to zwłaszcza integracji gospodarczej, kulturowej, politycznej itp. (Doliwa-Klepacki 2005, s. 37). W koncepcji ekonomicznej integrację rozumie się jako proces grupowania się. Ekonomista R. Marjolin stwierdza, że integracją jest każdy proces, który prowadzi do większego stopnia jedności (Doliwa-Klepacki 2005, s. 37). Mówiąc o integracji, warto wspomnieć o formach integracji ekonomicznej. Każdy szczebel jest krokiem do pełnej integracji, czyli unii ekonomicznej, która może stanowić etap integracji politycznej (Grabowski 2008, s. 16). Zazwyczaj wyróżnia się pięć form integracji: strefę wolnego handlu, unię celną, wspólny rynek, unię monetarną (walutową), pełną integrację (unię ekonomiczną). Formy integracji ekonomicznej przedstawia tabela 1.

Tabela 1. Formy integracji gospodarczej

\begin{tabular}{|l|l|l|l|l|l|}
\hline $\begin{array}{l}\text { Forma } \\
\text { integracji }\end{array}$ & $\begin{array}{l}\text { Wysoki sto- } \\
\text { pień liberali- } \\
\text { zacji wzajem- } \\
\text { nej wymiany } \\
\text { handlowej } \\
\text { (brak barier } \\
\text { we wzajemnej } \\
\text { wymianie } \\
\text { handlowej) }\end{array}$ & $\begin{array}{l}\text { Wspólna } \\
\text { polityka } \\
\text { handlowa, } \\
\text { zastosowanie } \\
\text { wspólnej } \\
\text { zewnętrznej } \\
\text { taryfy celnej } \\
\text { i barier poza- } \\
\text { taryfowych }\end{array}$ & $\begin{array}{l}\text { Swobodny } \\
\text { przepływ } \\
\text { czynników } \\
\text { produkcji } \\
\text { i towarów } \\
\text { wewnątrz } \\
\text { ugrupowania }\end{array}$ & $\begin{array}{l}\text { Harmonizacja } \\
\text { polityki eko- } \\
\text { nomicznej, } \\
\text { wspólna } \\
\text { waluta }\end{array}$ & $\begin{array}{l}\text { Pełna unifi- } \\
\text { kacja polityki } \\
\text { ekonomicznej } \\
\text { i zagranicznej, } \\
\text { w tym obron- } \\
\text { nej, wspólne } \\
\text { ponadnaro- } \\
\text { dowe organy } \\
\text { władzy }\end{array}$ \\
\hline $\begin{array}{l}\text { Strefa wol- } \\
\text { nego handlu }\end{array}$ & + & + & & & \\
\hline Unia celna & + & + & + & + & + \\
\hline $\begin{array}{l}\text { Wspólny } \\
\text { rynek }\end{array}$ & + & + & + & + & + \\
\hline $\begin{array}{l}\text { Unia } \\
\text { monetarna }\end{array}$ & + & + & + & + & + \\
\hline $\begin{array}{l}\text { Pełna } \\
\text { integracja }\end{array}$ & + & + & + & + & + \\
\hline
\end{tabular}

Źródło: (Proniewski, Niedźwiecki 2014, s. 31).

Pierwszym etapem integracji jest strefa wolnego handlu. Ta forma integracji gospodarczej usuwa różnorodne bariery handlowe, m.in. cła, ograniczenia ilościowe, bariery pozataryfowe, bariery parataryfowe. Likwidacja przeszkód jest 
możliwa wyłącznie w państwach unii. Wobec krajów trzecich członkowie ugrupowania prowadzą niezależną politykę handlową. Oznacza to, że stosowane bariery mogą być zróżnicowane, np. mogą obowiązywać różne stawki celne (Grabowski2008, s. 16).

Różne stawki celne są przyczyną konkurencji dóbr importowanych wśród krajów podlegających procesowi integracji. Tymczasem unia celna likwiduje rywalizację, wspierając tym samym handel pomiędzy członkami ugrupowania. Jednocześnie negatywnie wpływa na handel z krajami spoza unii (Grabowski 2008, s. 16).

Następną formą integracji jest wspólny rynek. Wspólny rynek powstaje na skutek porozumienia pomiędzy państwami. W odróżnieniu od strefy wolnego handlu i unii celnej, w przypadku których usuwane są bariery hamujące handel i ustalane wspólne cła, w przypadku wspólnego rynku otwierane są granice, aby umożliwić transfer czynników produkcji, czyli nakładów. Na danym etapie integracji kraje ugrupowania są zobowiązane do zastosowania bardziej „poważnych” narzędzi ekonomicznych. Kraje podlegające procesowi integracyjnemu na danym szczeblu zmuszone są do prowadzenia wspólnej polityki cenowej, podatkowej i innych. T. Grabowski stwierdza, że mechanizmy wspólnego rynku sa też z zasady stosowane przez kraje, które przewiduja osiaganie najwyższych możliwych szczebli integracji ekonomicznej (Grabowski 2008, s. 17).

Kolejny etap integracji, unia walutowa, jest bardziej skomplikowany. Pomimo obowiązywania wymienionych już wcześniej zasad integracji, w unii walutowej - zwanej również monetarną - podejmuje się działania na rzecz: zrównoważenia kursu walutowego (dopuszczalne są wahania w określonych granicach), zagwarantowania swobodnej wymienialności waluty o stałym kursie, stworzenia zbiorowej rezerwy walut oraz wspólnej waluty międzynarodowej, realizacji systemu pomocy kredytowej, a także utworzenia wspólnej polityki walutowej wobec krajów poza ugrupowaniem (Grabowski 2008, s. 17-18). Chcąc przystąpić do danego etapu integracji, kraje ubiegające się są zobowiązane do spełnienia warunków z zakresu m.in. polityki kredytowej banków centralnych, polityki budżetowej (Grabowski2008, s. 18).

Unia ekonomiczna, czyli pełna integracja, to najwyższa forma - i ostatni etap - integracji gospodarczej. Na tym szczeblu integracji jest prowadzona jednolita polityka, za którą odpowiadają instytucje międzynarodowe. Wszystkie kraje ugrupowania działają według wspólnych norm. Ta forma integracji gospodarczej obejmuje wszystkie wymienione funkcje integracji ekonomicznej. W takim ugrupowaniu obowiązuje jedna waluta, a więc wspólny bank centralny. Aby zaznaczyć spójność unii ekonomicznej i monetarnej, dany szczebel jest również nazywany unią ekonomiczno-monetarną lub ekonomiczno-walutową. Pełna integracja może prowadzić do unii politycznej (Grabowski 2008, s. 18). Wpływ integracji na gospodarkę Litwy warto badać, uwzględniając zróżnicowanie poszczególnych regionów. 


\section{Charakterystyka regionów Litwy}

Terytorium Republiki Litewskiej dzieli się na jednostki administracyjne. Jednostka administracyjna to część terytorium zarządzana przez Rząd Republiki Litewskiej lub instytucje samorządowe. Terytorialna jednostka administracyjna ma swoje granice, centrum oraz nazwę - są to okręgi (nazywane regionami) oraz samorządy (por. Lietuvos Respublikos teritorijos... 1994). Mapę okręgów Litwy przedstawia rysunek 1 .

Rysunek 1. Mapa okręgów Litwy

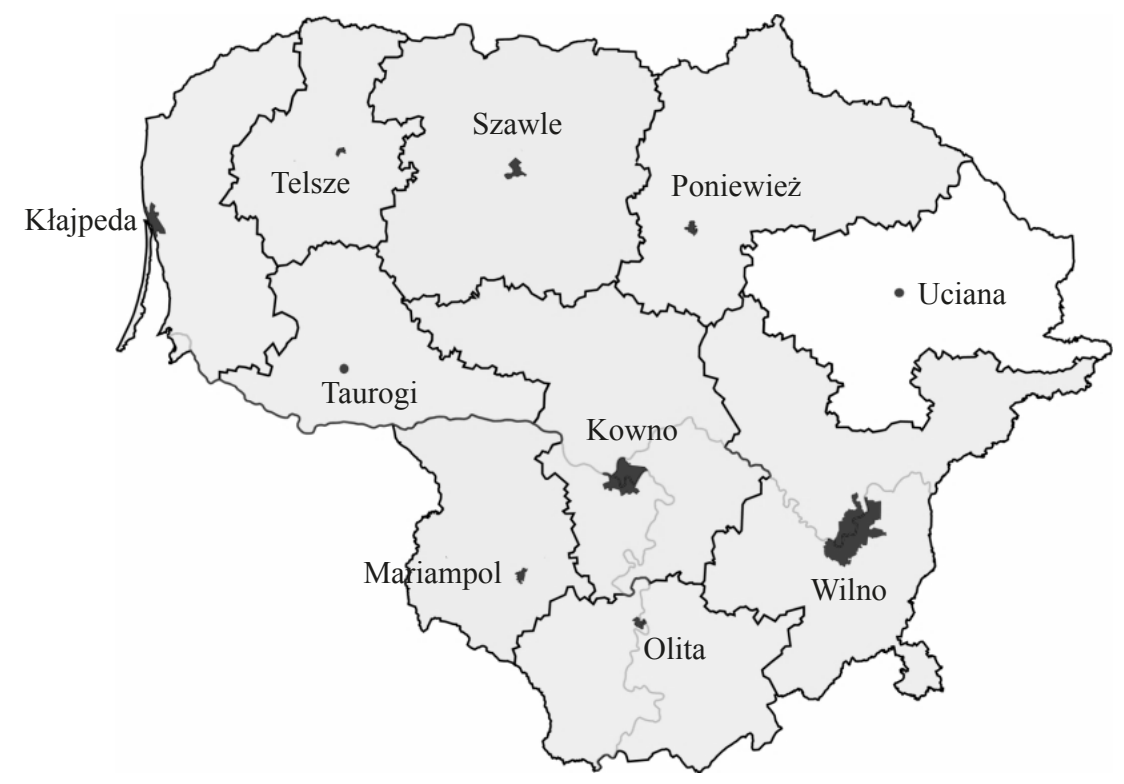

Źródło: opracowanie własne, www.osp.stat.gov.lt/regionine-statistika-pagal-statistikos-sritis (dostęp 26.10.2016).

Podział administracyjny Litwy obejmuje samorządy i okręgi, nazywane również regionami. Obecnie na Litwie jest 60 samorządów, które tworzą 10 okręgów: olicki, kowieński, kłajpedzki, mariampolski, poniewieski, szawelski, tauroski, telszański, uciański i wileński (por. Lietuvos Respublikos teritorijos... 2017).

Przez dłuższy czas, m.in. w latach 2004-2011, na Litwie mieszkało ponad $3 \mathrm{mln}$ osób. Jednakże z każdym rokiem liczba ludności malała. Aktualne dane wskazują, że Litwę zamieszkuje ok. 2,85 mln osób (2016 r. ). Wykres 1 obrazuje zmiany liczby ludności Litwy w ciągu 11 lat, począwszy od 2004 roku. 
Wykres 1. Liczba ludności Litwy w latach 2004-2015 (mln osób)

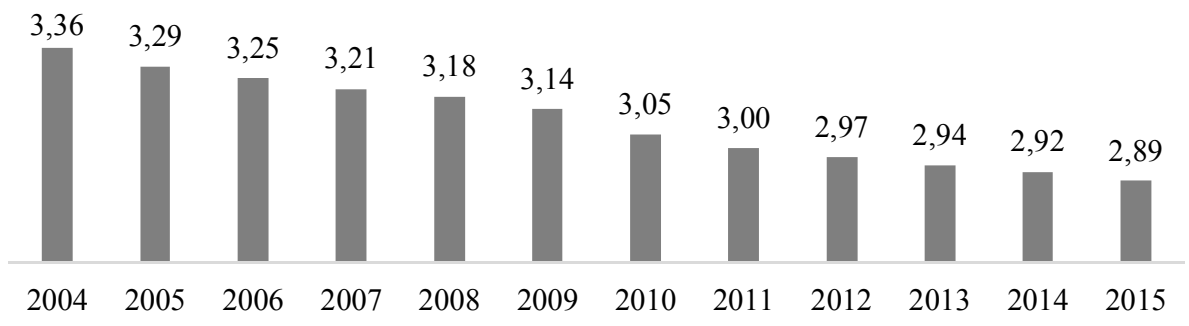

Źródło: appsso.eurostat.ec.europa.eu/nui/submitViewTableAction.do (dostęp 26.10.2016).

W 2004 roku na Litwie mieszkało 3,36 mln osób, jednak z każdym rokiem liczba ludności malała. W 2004 r. Unia Europejska otworzyła swoje granice dla Litwy, co spowodowało, że ludzie zaczęli emigrować w poszukiwaniu bardziej opłacalnej pracy. Największy spadek odnotowano w 2010 roku. Pięć lat później liczba ludności na Litwie wynosiła 2,89 mln osób, czyli o 16\% mniej niż w 2004 roku.

Regiony Litwy są nierównomiernie zaludnione. Najwięcej osób zamieszkuje okręgi wileński, kowieński oraz kłajpedzki. Duży wpływ na tę sytuację ma emigracja mieszkańców z mniej rozwiniętych regionów w celu znalezienia lepszych warunków do życia. Rysunek 2 obrazuje regionalne zróżnicowanie ludności Litwy pod koniec 2015 roku.

Rysunek 2. Regionalne zróżnicowanie ludności Litwy pod koniec 2015 roku

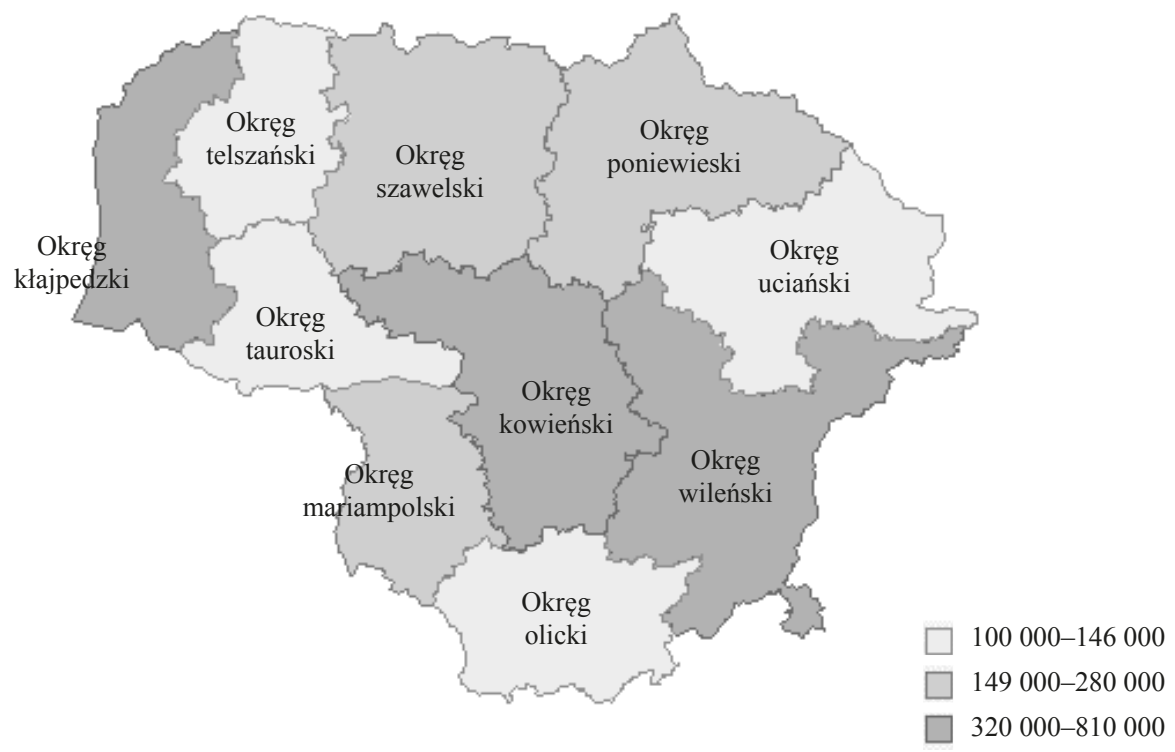

Źródło: www.osp.stat.gov.lt/statistiniu-rodikliu-analize1 (dostęp 26.10.2016). 
Regiony tauroski, uciański i olicki są najmniej zaludnione. Zamieszkuje je od 100 tys. do 146 tys. osób, czyli ponad 18\% ludności całego kraju. 149 tys. 280 tys. osób mieszka w okręgach mariampolskim, poniewieskim i szawelskim; jest to prawie 23\% mieszkańców Litwy. Najbardziej zaludnionymi okręgami są kłajpedzki, kowieński oraz wileński, które zamieszkuje od 320 tys. do 810 tys. osób, co stanowi ponad 59\% ludności. Powodem tego może być niezrównoważony rozwój gospodarczy regionów kraju.

Kolejnym miernikiem wskazującym na duże zróżnicowanie regionalne są wydatki na badania i rozwój. Działalność badawczo-rozwojowa ma nieoceniony wpływ na rozwój społeczno-gospodarczy regionów. Wydatki na badania i rozwój w sektorze rządowym i szkolnictwa wyższego w 2015 roku na Litwie przedstawia wykres 2 .

Wykres 2. Wydatki na badania i rozwój w sektorze rządowym i szkolnictwa wyższego w 2015 r. (mln euro)

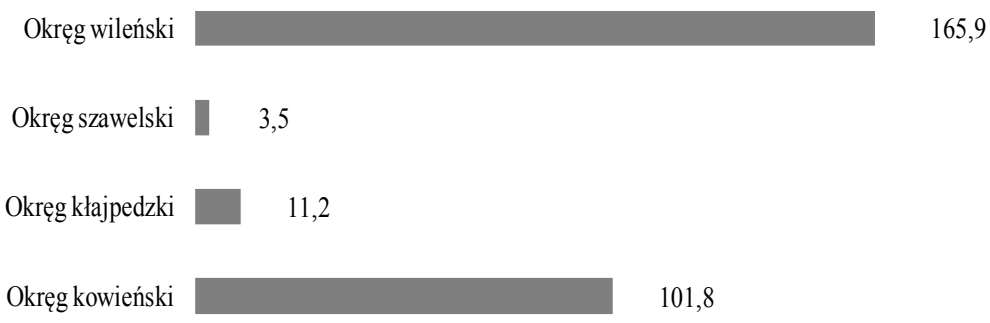

Źródło: www.osp.stat.gov.lt/documents/10180/3329771/MTEP.pdf (dostęp 28.02.2017).

Działania badawczo-rozwojowe prowadzone są głównie w 4 okręgach: wileńskim, szawelskim, kłajpedzkim oraz kowieńskim. Najwięcej środków na badania i rozwój przeznacza się w okręgu wileńskim - 165,9 mln euro. Nieco mniej w okręgu kowieńskim - 101,8 mln euro, a najmniej w okręgu szawelskim (3,5 mln euro).

Aby finansować badania i rozwój kraj powinien dysponować niezbędnymi środkami. Jednym z głównych źródeł środków inwestycyjnych płynących do kraju są Fundusze Strukturalne Unii Europejskiej. Zasadnicze znaczenie, jeśli chodzi o absorpcję środków unijnych, ma podział Litwy na regiony według Klasyfikacji Jednostek Terytorialnych do Celów Statystycznych (NUTS)1. Podział NUTS przedstawia tabela 1 .

NUTS służy do podziału terytorium państw Unii Europejskiej na trzy poziomy regionalne i uwzględnia liczbę ludności na danych obszarach, podczas

\footnotetext{
${ }^{1}$ Klasyfikacja NUTS została stworzona w celu zbierania porównywalnych danych społeczno-gospodarczych w regionach Unii Europejskiej. Klasyfikacja Jednostek Terytorialnych do Celów Statystycznych została wdrożona rozporządzeniem Parlamentu Europejskiego i Rady z dnia 26 maja 2003 roku, jednak weszła w życie 11 lipca 2003 roku.
} 
gdy lokalne jednostki administracyjne (LAU) są bardziej szczegółowe. Pierwszy poziom (LAU 1) obejmuje samorządy (savivaldybès) a drugi (LAU 2) - gminy (seniünijos).

Tabela 1. Klasyfikacja NUTS

\begin{tabular}{|l|l|l|}
\hline Poziom & Opis & Przedział (osoby) \\
\hline NUTS 0 & Państwo & - \\
\hline NUTS 1 & \multirow{3}{*}{ Poziom regionalny } & $3 \mathrm{mln}-7 \mathrm{mln}$ \\
NUTS 2 & & 800 tys. $-3 \mathrm{mln}$ \\
NUTS 3 & & 150 tys. -800 tys. \\
\hline LAU 1 & \multirow{2}{*}{ Poziom lokalny } & - \\
\hline LAU 2 & & - \\
\hline
\end{tabular}

Źródło: www.stat.gov.pl/statystyka-regionalna/jednostki-terytorialne/klasyfikacja-nuts/historia-klasyfikacji-nuts (dostęp: 2.04.2017).

Do 2016 roku terytorium Litwy dzieliło się na jeden region z poziomu NUTS 1 i NUTS 2 oraz dziesięć regionów z poziomu NUTS 3. Przy czym NUTS 3 to 10 okręgów Litwy: olicki, kowieński, kłajpedzki, mariampolski, poniewieski, szawelski, tauroski, telszański, uciański, wileński.

W 2016 roku podział ten został zmieniony - 6 stycznia 2016 r. rząd Republiki Litewskiej zatwierdził dwa nowe regiony: region Stolicy, czyli okręg wileński, oraz region Litwy Środkowej i Zachodniej, obejmujący pozostałe dziewięć okręgów. Tak więc od 2016 roku na Litwie funkcjonują: jeden region z poziomu NUTS 1 - Litwa, trzy z poziomu NUTS 2 - Litwa, region Stolicy, region Litwy Środkowej i Zachodniej oraz 10 NUTS 3 - 10 okręgów Litwy. Podział wprowadzono z powodu różnicowania rozwoju okręgów Litwy.

Region wileński jest najbardziej rozwinięty i przyciąga najwięcej inwestycji, mieszczą się w nim główne siedziby przedsiębiorstw i siedziby rządowe. Wszystko to powoduje, że okręg wileński „ciągnie” do góry krajowe PKB - PKB na jednego mieszkańca regionu wileńskiego stanowi 110\% średniej Unii Europejskiej, a w pozostałej części Litwy nie osiąga 75\% średniej unijnej. Taki stan rzeczy, tj. bez wprowadzenia zmian w klasyfikacji NUTS, mógłby oznaczać zmniejszenie wsparcia Unii Europejskiej w 2021 roku nawet do poziomu 60\%. Dlatego też, aby nie stracić prawie 2,7 mld euro, rząd Litwy podjął decyzję o podziale Litwy na dwa regiony - zamożniejsze Wilno oraz mniej rozwiniętą Srodkową i Zachodnią Litwę (por. Pritarta Sostinès regiono... 2017). 


\section{Źródła finansowania i analiza rozwoju regionalnego Litwy w latach 2004-2015}

Głównym zewnętrznym źródłem finansowania Litwy są środki Unii Europejskiej. Budżetem Unii Europejskiej zarządza głównie pięć największych funduszy (por. Europejskie Fundusze Strukturalne... 2016): Europejski Fundusz Rozwoju Regionalnego, Europejski Fundusz Społeczny, Fundusz Spójności, Europejski Fundusz Rolny na rzecz Rozwoju Obszarów Wiejskich, Europejski Fundusz Morski i Rybacki.

Po wstąpieniu do Unii Europejskiej Litwa mogła korzystać ze środków pieniężnych Unii, aby realizować plany zawarte w jednolitym dokumencie programowym $^{2}$ oraz założenia polityki spójności. Na osiągnięcie tych celów przeznaczono 1,720 mld euro (por. ES investicijos 2017). Priorytetami określonymi w jednolitym dokumencie programowym były: rozwój infrastruktury społecznej i gospodarczej, rozwój sektora produkcyjnego, rozwój obszarów wiejskich i rybołówstwa, rozwój zasobów ludzkich oraz wsparcie techniczne (por. Dél Lietuvos 2004-2006 metu... 2004).

W latach 2007-2013 Litwa pozyskała środki z: Europejskiego Funduszu Społecznego, Europejskiego Funduszu Rozwoju Regionalnego oraz Funduszu Spójności (por. ES investicijos 2017). Sfinansowane zostały cztery programy operacyjne: rozwój zasobów ludzkich, wzrost gospodarczy, promowanie spójności i wspieranie działalności technicznej. Na wymienione programy przeznaczono ponad 6,775 mld euro. Obecna perspektywa budżetowa obejmuje lata 2014-2020, w których główną rolę odgrywa strategia „Europa 2020”. Jej celem jest sprzyjanie wzrostowi gospodarczemu i tworzenie nowych miejsc pracy, które przyspieszą rozwój całej Unii Europejskiej. Na ten cel Litwie przydzielono 6,709 mld euro.

Po przystąpieniu do Unii Europejskiej Litwa otrzymała też pomoc w ramach mechanizmów finansowych stworzonych przez Norwegię, Islandię oraz Lichtenstein. Istotne znaczenie miało również wsparcie Federacji Szwajcarskiej w wysokości 63,317 mln CHF.

Produkt krajowy brutto jest jednym z podstawowych mierników rozwoju. Wartościowe i procentowe ujęcie PKB w poszczególnych regionach Litwy przedstawia tabela 2 . Analizie poddano lata uwzględniające okresy rozpoczęcia nowych perspektyw budżetowych w Unii Europejskiej oraz rok 2015.

\footnotetext{
${ }^{2}$ Jednolity dokument programowy - dokument sporządzany przez rząd w celu uzyskania środków pieniężnych z funduszy strukturalnych zawierający plan wydatkowania otrzymanej pomocy finansowej.
} 
Tabela 2. PKB w poszczególnych okręgach

\begin{tabular}{|l|c|c|c|c|c|c|c|c|}
\hline \multirow{2}{*}{ Okręgi } & \multicolumn{2}{|c|}{2004} & \multicolumn{2}{c|}{2007} & \multicolumn{2}{c|}{2014} & \multicolumn{2}{c|}{2015} \\
\cline { 2 - 9 } & $\begin{array}{c}\text { mln } \\
\text { euro }\end{array}$ & $\begin{array}{c}\text { udział } \\
\text { wKB } \\
\text { kraju } \\
(\%)\end{array}$ & $\begin{array}{c}\text { mln } \\
\text { euro }\end{array}$ & $\begin{array}{c}\text { udział } \\
\text { w PKB } \\
\text { kraju } \\
(\%)\end{array}$ & $\begin{array}{c}\text { mln } \\
\text { euro }\end{array}$ & $\begin{array}{c}\text { udział } \\
\text { w PKB } \\
\text { kraju } \\
(\%)\end{array}$ & $\begin{array}{c}\text { mln } \\
\text { euro }\end{array}$ & $\begin{array}{c}\text { udział } \\
\text { wKB } \\
\text { kraju } \\
(\%)\end{array}$ \\
\hline olicki & 676,4 & 3,7 & 995,8 & 3,4 & 1211,1 & 3,3 & 1212,2 & 3,2 \\
\hline kowieński & 3471,0 & 19,0 & 5592,6 & 19,3 & 7223,0 & 19,7 & 7394,5 & 19,8 \\
\hline kłajpedzki & 2087,3 & 11,4 & 3326,5 & 11,5 & 4301,5 & 11,8 & 4315,9 & 11,6 \\
\hline mariampolski & 627,8 & 3,4 & 935,5 & 3,2 & 1206,8 & 3,3 & 1185,5 & 3,2 \\
\hline poniewieski & 1302,5 & 7,1 & 1710,7 & 5,9 & 2200,7 & 6,0 & 2251,5 & 6,0 \\
\hline szawelski & 1456,4 & 8,0 & 2151,2 & 7,4 & 2641,1 & 7,2 & 2681,9 & 7,2 \\
\hline tauroski & 354,8 & 1,9 & 493,3 & 1,7 & 728,1 & 2,0 & 731,5 & 2,0 \\
\hline telszański & 829,4 & 4,5 & 1234,5 & 4,3 & 1317,9 & 3,6 & 1327,0 & 3,6 \\
\hline uciański & 829,7 & 4,5 & 1161,0 & 4,0 & 1166,4 & 3,2 & 1148,4 & 3,1 \\
\hline wileński & 6602,3 & 36,2 & 11439,5 & 39,4 & 14593,5 & 39,9 & 15081,9 & 40,4 \\
\hline ogółem & 18237,7 & 100,0 & 29040,7 & 100,0 & 36590,0 & 100,0 & 37330,5 & 100,0 \\
\hline
\end{tabular}

Źródło: www.osp.stat.gov.lt/statistiniu-rodikliu-analize1 (dostęp 21.12.2016).

Z tabeli 2 wynika, że największy udział w PKB w 2004 roku miał okręg wileński. Jego PKB wyniosło $6602,3 \mathrm{mln}$ euro, a w ujęciu procentowym $36,2 \%$, czyli ponad jedną trzecią PKB całego kraju. W 2015 roku PKB okręgu wileńskiego stanowiło już ponad 40\% krajowego. Mniej produktywny okazuje się okręg kowieński. W 2004 roku PKB okręgu kowieńskiego wynosiło $3471 \mathrm{mln}$ euro, lecz już w 2014 roku ta liczba wzrosła ponaddwukrotnie. W 2015 roku udział okręgu kowieńskiego w PKB całego kraju wyniósł 19,8\%. Kolejnym okręgiem, jeśli chodzi o stopień produktywności, jest okręg kłajpedzki. W 2004 roku PKB okręgu kłajpedzkiego wyniosło 2 087,3 mln euro (tj. 11,4 \% PKB krajowego), a w 2015 roku - 11,6\%. Najmniejszy udział w PKB ma okręg tauroski $-2 \%$.

Kolejnym istotnym wskaźnikiem charakteryzującym rozwój regionu jest stopa zatrudnienia. Pokazuje ona, jaki procent osób zatrudnionych pracuje zawodowo. Za osobę zatrudnioną uważa się człowieka, który ukończył 15 rok życia, pracuje i otrzymuje wynagrodzenie. Tabela 3 przedstawia stopę zatrudnienia osób w wieku 15-64 lat. 
Tabela 3. Stopa zatrudnienia na Litwie wśród osób w wieku 15-64 lat w przekroju lat 2004-2015

\begin{tabular}{|l|c|c|c|c|c|}
\hline Okręgi & 2004 & 2007 & 2014 & 2015 & Dynamika \\
\hline olicki & 55,6 & 61,7 & 58,3 & 61,8 & 111,2 \\
\hline kowieński & 63,1 & 65,7 & 67,1 & 68,4 & 108,4 \\
\hline kłajpedzki & 60,8 & 65,4 & 68,5 & 70,9 & 116,6 \\
\hline mariampolski & 62,1 & 66,4 & 61,5 & 64,3 & 103,5 \\
\hline poniewieski & 59,9 & 61,2 & 60,7 & 62,8 & 104,8 \\
\hline szawelski & 58,8 & 61,2 & 61,6 & 61,3 & 104,3 \\
\hline tauroski & 62,8 & 63,5 & 62,8 & 67,9 & 108,1 \\
\hline telszański & 60,7 & 66,3 & 63,0 & 64,4 & 106,1 \\
\hline uciański & 58,9 & 65,5 & 60,2 & 61,5 & 104,4 \\
\hline wileński & 63,9 & 67,2 & 70,2 & 70,9 & 111,0 \\
\hline ogółem & 61,6 & 65,0 & 65,7 & 67,2 & 109,1 \\
\hline
\end{tabular}

Źródło: www.osp.stat.gov.lt/statistiniu-rodikliu-analize1 (dostęp 21.12.2016).

Stopa zatrudnienia na Litwie wykazuje tendencję wzrostową, chociaż nie da się ukryć, że kryzys gospodarczy miał wpływ na poziom zatrudnienia. W 2008 roku analizowany wskaźnik spadł z $65 \%$ do $64,4 \%$. Ponownie zaczął rosnąć w 2012 roku, po wcześniejszym spadku do 60,2\% (w 2011 roku). W 2015 roku w poszczególnych regionach Litwy wskaźnik zatrudnienia wahał się od $60 \%$ do $70 \%$. Najwyższa stopa zatrudnienia była w okręgu wileńskim oraz kłajpedzkim (70,9\%), a ponadto okręg kłajpedzki miał największą dynamikę wzrostu. Zatrudnienie w tym regionie wzrosło o 16,6\%. O 11,2\% wzrósł wskaźnik w okręgu olickim, w którym jeszcze w 2004 roku stopa zatrudnienia była najniższa. W 2015 roku najmniejszy wskaźnik był w okręgu szawelskim (61,3\%).

Przeciwieństwem stopy zatrudnienia jest wskaźnik stopy bezrobocia. Według departamentu statystyki osobą bezrobotną jest osoba w wieku od 15 do 74 lat, która nie pracuje ani nie uczy się, aktywnie poszukuje pracy i jest zdolna do jej podjęcia. Obecnie stopa bezrobocia na Litwie wynosi 7,9\% (2016 rok). Tabela 4 prezentuje stopę bezrobocia na Litwie osób w wieku od 15 lat i starszych w poszczególnych okręgach w latach 2004-2015.

Tabela 4. Stopa bezrobocia na Litwie wśród osób wieku 15 lat i starszych w przekroju lat 2004-2015

\begin{tabular}{|l|r|r|r|r|c|}
\hline Okręgi & 2004 & 2007 & 2014 & 2015 & Dynamika \\
\hline olicki & 14,6 & 3,3 & 18,5 & 15,4 & 105,5 \\
\hline kowieński & 10,1 & 4,2 & 8,9 & 7,2 & 71,3 \\
\hline kłajpedzki & 12,5 & 3,9 & 7,7 & 6,0 & 48,0 \\
\hline mariampolski & 6,6 & 1,6 & 13,0 & 10,4 & 157,6 \\
\hline
\end{tabular}




\begin{tabular}{|l|r|r|r|r|r|}
\hline poniewieski & 11,9 & 6,4 & 13,7 & 12,0 & 100,8 \\
\hline szawelski & 12,0 & 4,5 & 12,9 & 13,0 & 108,3 \\
\hline tauroski & 8,3 & 2,7 & 11,6 & 9,1 & 109,6 \\
\hline telszański & 9,6 & 4,5 & 12,4 & 10,3 & 107,3 \\
\hline uciański & 12,0 & 4,4 & 17,4 & 14,0 & 116,7 \\
\hline wileński & 10,6 & 4,5 & 8,5 & 7,6 & 71,7 \\
\hline ogółem & 10,9 & 4,2 & 10,7 & 9,1 & 83,5 \\
\hline
\end{tabular}

Źródło: www.osp.stat.gov.lt/statistiniu-rodikliu-analize1 (dostęp 21.12.2016).

$\mathrm{Z}$ tabeli 5 wynika, że najmniejszą stopę bezrobocia na Litwie odnotowano tuż przed ogólnoświatowym kryzysem gospodarczym, tj. w 2007 roku - ogółem w kraju wskaźnik wyniósł 4,2\%. Najmniejsze bezrobocie w 2007 roku było w okręgu mariampolskim $(1,6 \%)$, a największe w okręgu poniewieskim $(6,4 \%)$. Po rozpoczęciu kryzysu bezrobocie wzrosło ponaddwukrotnie. W roku 2015 stopa bezrobocia w kraju wynosiła 9,1\%, przy czym największa była w okręgu olickim $(15,4 \%)$, a najmniejsza w kłajpedzkim (6\%). Duży spadek stopy bezrobocia odnotowano w okręgu kłajpedzkim (dynamika wynosi 48\%). Wskaźnik bezrobocia spadł też w okręgach kowieńskim oraz wileńskim. W pozostałych regionach stopa bezrobocia wzrosła. Największy wzrost zaobserwowano w okręgu mariampolskim (57\%).

Resumując rozważania na temat rozwoju regionów Litwy, należy stwierdzić, że środki Unii Europejskiej miały pozytywny wpływ na rozwój gospodarki litewskiej. Przed wstąpieniem do UE PKB Litwy stanowiło 46\% średniej unijnej, a w 2014 roku wzrosło do 75\%. Dzięki funduszom UE Litwa była w stanie szybciej przezwyciężyć trudności gospodarcze oraz zmniejszyć liczbę bezrobotnych (por. Członkostwo Litwy w UE 2017).

$\mathrm{Z}$ analizy regionów Litwy wynika, że najbardziej rozwinięte okręgi to wileński, kowieński oraz kłajpedzki. Silny rozwój pierwszego z nich przesądził o nowym podziale Litwy - na region Stolicy oraz region Litwy Środkowej i Zachodniej. Stało się tak z powodu dużego zróżnicowania rozwoju okręgów oraz dążenia do pozyskania jak największych środków unijnych.

W wymienionych regionach rozwój widoczny jest przede wszystkim w głównych miastach. Wilno jest stolicą i największym miastem na Litwie, uznawanym za centrum gospodarcze, finansowe i handlowe. W 2015 roku PKB okręgu wileńskiego stanowiło 40,4\% PKB krajowego, a PKB per capita wynosiło 18,7 tys. euro. Większość inwestycji zagranicznych jest skierowana do Wilna. Duża liczba centrów usług wspólnych jest ulokowana w stolicy, m.in. Western Union, Barclays, Swedbank, SEB, Computer Science Corporation (CSC), Danske Bank (por. Business Guide 2015).

Kowno ma dobrze rozwinięty transport drogowy, kolejowy oraz infrastrukturę zarówno wodną, jak i powietrzną. W 2015 roku okręg kowieński wytworzył 19,8\% ogólnego PKB i 12,7 tys. euro PKB per capita. Region skupia się na 
innowacjach i rozwoju technologicznym. W Kownie są umieszczone dwa centra nauki, badań i rozwoju - Santaka oraz Nemunas. Centrum Santaka zostało założone w celu prowadzenia badań naukowych, aby stworzyć przedsiębiorstwa oparte na wiedzy oraz usługi o wartości dodanej. Nemunas sprzyja rozwojowi w sektorze żywnościowym, rolnictwa i leśnictwa. Coraz więcej firm z branży IT decyduje się na inwestycje w Kownie; są to m.in.: Callcredit, Intermedix, Virtustream (por. Business Guide 2015).

W porcie kłajpedzkim jest najmniej lodu w porównaniu z innymi północnymi portami na wschodnim wybrzeżu Morza Bałtyckiego. W 2013 roku stworzono lepsze warunki do obsługi dużych statków dzięki bagrowaniu. Rekonstrukcja portu zwiększyła jego konkurencyjność. Mocną stroną Kłajpedy jest zarówno przemysł stoczniowy, jak i transport wraz z logistyką. W odległości $35 \mathrm{~km}$ od miasta znajduje się port lotniczy Połąga, co jest mocną stroną regionu. W 2015 roku okręg kłajpedzki wytworzył 11,6\% PKB Litwy (por. Business Guide 2015), a PKB na osobę wyniosło 13,2 tys. euro.

W 2015 roku Międzynarodowy Fundusz Walutowy uznał, że Litwa jest w grupie gospodarek zaawansowanych, takich jak Niemcy, Stany Zjednoczone oraz Japonia. Podczas podziału państw na grupy gospodarek zaawansowanych oraz wschodzących i rozwijających się uwzględniane są PKB per capita, dywersyfikacja eksportu oraz stopień integracji globalnego systemu finansowego. Ponadto Litwa jest wysokorozwinięta $\mathrm{w}$ dziedzinie edukacji i technologii (por. IMF - Lithuania no longer... 2015).

Warto też wspomnieć, że Litwa słynie z laserów, które są wytwarzane m.in. w Wilnie. Około 50\% laserów na świecie pochodzi z Europy, a największy udział w sprzedaży mają Francja, Niemcy oraz Litwa. Ponad 80\% laserów Litwa sprzedaje za granicę. Na początku 2015 roku litewskie lasery były eksportowane na takie kontynenty jak: Europa (50,5\%), Azja (28,2\%), Ameryka Północna (20,1\%), Oceania $(0,7 \%)$, Ameryka Południowa (0,3\%) i Afryka (0,2\%) (Piskarskas i in. 2015, s. 7-8).

\section{Podsumowanie}

Począwszy od 1 maja 2004 roku Litwa jako pełnoprawny członek Unii Europejskiej uzyskuje środki finansowe z funduszy unijnych w celu realizacji licznych projektów. Środki te dynamizują rozwój regionów Litwy i gospodarki jako całości.

W latach 2004-2015 PKB wzrosło w każdym regionie Litwy. Analiza udziału PKB regionów w PKB kraju pokazała, że największy udział występuje w przypadku okręgów wileńskiego, kowieńskiego i kłajpedzkiego. Świadczy to o wyraźnej polaryzacji procesów rozwojowych skupiających się w trzech najbardziej rozwiniętych regionach Litwy. Analiza PKB per capita wskazuje tendencję wzrostową we wszystkich regionach. Pozytywnie świadczy to o przebiegu procesu rozwoju regionalnego przy użyciu m.in. środków unijnych. 
Istotnym wskaźnikiem, który został poddany analizie, była stopa zatrudnienia. Zauważono, że w 2008 roku kryzys gospodarczy miał negatywny wpływ na stopę zatrudnienia, co nie zmienia faktu, że w badanym okresie, czyli w latach 2004-2015, wskaźnik ten wzrósł łącznie o ponad 9\%. Najmniejszy przyrost wyniósł $3,5 \%$ i został odnotowany w okręgu mariampolskim. Największy, o wartości 16,6\%, wystąpił w okręgu kłajpedzkim.

Wskaźnikiem bezpośrednio związanym ze stopą zatrudnienia jest stopa bezrobocia. Badania pokazują, że w żadnym okręgu Litwy nie powtórzył się tak niski poziom bezrobocia, jaki miał miejsce w 2007 roku. W większości regionów dynamika stopy bezrobocia jest dodatnia. Zauważono wyraźny wzrost bezrobocia w 2015 roku w porównaniu z rokiem 2004. Najlepiej z problemem bezrobocia radzą sobie okręgi kłajpedzki, kowieński i wileński, co wynika głównie z większego stopnia ich rozwoju względem regionów pozostałych.

Z przeprowadzonej analizy wynika, że po przystąpieniu Litwy do Unii Europejskiej większość badanych wskaźników uległa pozytywnym zmianom. Najwyższy poziom rozwoju wśród regionów litewskich osiąga okręg wileński. Tuż za nim plasują się regiony kowieński i kłajpedzki. W związku ze znacznym rozwojem okręgu wileńskiego i jego przewagą nad pozostałymi regionami na Litwie wprowadzono nowy podział regionalny według klasyfikacji NUTS - na nowo powstały region Stolicy i Litwy Środkowo-Zachodniej. Skutkiem tego ma być większa i lepsza alokacja środków unijnych.

\section{Bibliografia}

Business Guide Lithuania 2015, pwc.com, www.pwc.com/lt/lt/assets/publications/businessguide2015_web.pdf (data dostępu: 4.03.2017).

Członkostwo Litwy w UE, Ministerstwo Spraw Zagranicznych, urm.lt, www.urm. 1t/default/pl/polityka-zagraniczna/Litwa-w-Unii-Europejskiej/czonkostwolitwy-w-ue (data dostępu: 5.03.2017).

Departament statystyki Litwy, osp.stat.gov.lt, www.osp.stat.gov.lt/statistiniu-rodikliu-analize1 (data dostępu: 26.10.2016).

Doliwa-Klepacki Z.M. (2005), Integracja europejska, Temida 2, Białystok.

ES investicijos, Ministerstwo Finansów Litwy, http://finmin.lrv.lt, http://finmin. lrv.lt/lt/es-ir-kitos-investicijos/es-investicijos (data dostępu: 7.12.2016).

Europejskie Fundusze Strukturalne i Inwestycyjne na lata 2014-2020: Teksty urzędowe $i$ komentarze, Urząd Publikacji Unii Europejskiej, Luksemburg 2016, s. 202, 220, 242, 324, 255.

Eurostat, ec.europa.eu/eurostat, www.appsso.eurostat.ec.europa.eu/nui/submitView TableAction.do (data dostępu: 26.10.2016).

Grabowski T. (2008), Unia europejska - mechanizmy integracji gospodarczej, Wydawnictwo Adam Marszałek, Toruń. 
Historia klasyfikacji NUTS, Główny Urząd Statystyczny, http://stat.gov.pl, http:// stat.gov.pl/statystyka-regionalna/jednostki-terytorialne/klasyfikacja-nuts/ historia-klasyfikacji-nuts/ (data dostępu: 2.04.2017).

IMF - Lithuania no longer a developing economy, The Baltic Times, baltictimes. com, www.baltictimes.com/imf_-_lithuania_no_longer_a_developing_economy (data dostępu: 4.03.2017).

Lietuvos Respublikos teritorijos administracinis suskirstymas, Departament Statystyki Litwy, https://osp.stat.gov.lt/regionine-statistika-pagal-statistikos-sritis (data dostępu: 26.10.2016).

Lietuvos Respublikos teritorijos administraciniu vienetu ir ju ribu istatymas, Valstybès žinios, 1994.08.05, nr 60-1183.

Machlup F. (1986), Integracja gospodarcza - narodziny i rozwój idei, Państwowe Wydawnictwo Naukowe, Warszawa.

Moksliniu tyrimu ir eksperimentinès (socialinès, kulturinès) pletros veikla, Departament Statystyki Litwy, www.osp.stat.gov.lt/documents/10180/3329771/ MTEP.pdf (data dostępu: 28.02.2017).

Nutarimas dèl Lietuvos 2004-2006 metu bendrojo programavimo dokumento patvirtinimo, www.e-tar.lt/portal/lt/legalAct/TAR.AEF225494516 (data dostępu: 07.12.2016).

Oficialiosios statistikos portalas, www.osp.stat.gov.lt/statistiniu-rodikliu-analize1 (data dostępu: 21.12.2016).

Piskarskas A.P., Balkevičius P., Račiukai G. et al. (2015), Laser Technologies in Lithuania 2015, Lietuvos lazeriu asociacija, Vilnius.

Pritarta Sostines regiono ir Vidurio ir vakaru Lietuvos regiono sudarymui, Ministerstwo Spraw Zagranicznych Litwy, http://vrm.lrv.lt/lt/naujienos/pritarta-sostines-regiono-ir-vidurio-ir-vakaru-lietuvos-regiono-sudarymui (data dostępu: 1.03.2017).

Proniewski M., Niedźwiecki A. (2004), Formy europejskiej integracji gospodarczej, Wydawnictwo Uniwersytetu w Białymstoku, Białystok.

Szarfenberg R., Szewczyk Ł. (2010), Badania ubóstwa - perspektywa ilościowa i jakościowa, [w:] R. Szarfenberg, Ł. Szewczyk, M. Theiss, Ubóstwo i wykluczenie społeczne - perspektywa poznawcza, Dom Wydawniczy ELIPSA, Warszawa.

\section{Streszczenie}

W artykule została podjęta tematyka rozwoju regionalnego Litwy w warunkach integracji gospodarczej, a jego celem jest analiza poszczególnych regionów Litwy pod kątem ich rozwoju i wskazanie na wewnętrzne regionalne zróżnicowanie kraju. Do przeanalizowania wymienionych czynników wykorzystano metodę statystyki opisowej. Poddano analizie szereg wskaźników; są to m.in. PKB, stopa 
bezrobocia, stopa zatrudnienia. Po przystąpieniu do Unii Europejskiej Litwa, jako pełnoprawny członek ugrupowania, uzyskuje środki pomocnicze $\mathrm{w}$ celu realizacji projektów rozwojowych. Produkt krajowy brutto jest jednym z głównych wskaźników służących ocenie stanu gospodarki kraju. Analiza udziału PKB regionów w PKB kraju wykazała, że największy udział mają okręgi wileński, kowieński i kłajpedzki. Dodatkowo w przypadku PKB per capita analiza wykazała wzrostową tendencję we wszystkich regionach. $\mathrm{Z}$ przeprowadzonych analiz procesu rozwoju regionalnego wynika, że po przystąpieniu Litwy do Unii Europejskiej większa część badanych wskaźników uległa pozytywnym zmianom, m.in. dzięki wykorzystaniu środków unijnych.

Słowa kluczowe: rozwój regionalny, Litwa, Unia Europejska, integracja gospodarcza, okręg

\section{Summary}

\section{Regional Development of Lithuania Under Conditions of Economic Integration}

This study analyses regional development of Lithuania in terms of economic integration. The aim of the study is the analysis of individual regions of Lithuania in order to show a level of their development and the indication of inner regional differentiation of the country. To achieve that the method of descriptive statistics was used. A number of indicators were analyzed, such as GDP, investments and pollution emissions. After the accession to the European Union, Lithuania, as a full-fledged member of the grouping, obtained auxiliary measures to realize the development projects. Gross domestic product is one of the main indicators which are used to estimate the state of the economy of the country. Analysis of the influence of each regions' GDP on the overall GDP of the country showed that the largest participation occurs in the districts of Vilnius, Kaunas and Klaipeda. Moreover, analysis of the GDP per capita showed an increasing trend in all the regions. It is seen, from the analysis conducted of the process of regional development, that after Lithuanian's accession to European Union, the greater part of the indicators changed in a positive way, also because of the unions' funds.

Keywords: regional development, Lithuania, European Union, economic integration, county

JEL: O10, R10 